\title{
The Janus Face of Normativities in a Global Mirror: Viewing 16th-Century Marriage Practices in Japan from Christian and Japanese Traditions
}

\author{
Luisa Stella de Oliveira Coutinho Silva
}

Since the 13th century, the Ashikaga clan governed Japan as shōguns (military rulers). During the rule of Ashikaga Yoshiharu, the 12th shōgun of the Muromachi period (1336-1573), Japan was amid the turmoil of a civil war. Due to the lack of political articulation, the effective power of the shōgun was diminishing considerably day by day. To complicate this scenario, something unique happened for the first time on Japanese soil: in 1543, Portuguese travelers arrived in the island of Tanegashima aboard Chinese junk ships, making the first contact between Japan and Europe. ${ }^{1}$ Six years later, the first Jesuits in Japan, Francisco Xavier, Cosme de Torres, and Juan Fernández, landed in today's Kagoshima, at that time part of the Satsuma fief, and began the Christian mission in Japan. After these events, an increasing number of missionaries came to Japan, developed their evangelical mission, and attempted to forge alliances with daimyōs (local warlords) and shōguns.

From that moment, Christians began to document their life, their preaching, and their mission in Japan. Today, this corpus of sources can be found in different parts of the world in Jesuit, Franciscan, and Dominican archives. Descriptions about early Christian life in Japan can also be found in national archives around the world: in Tokyo, Madrid, Mexico City, Lisbon, Seville, and Manila, to name a few. This includes official correspondence with monarchs in Europe, histories of Japan, descriptions and letters, and instructions for the captains of the official trips from China to Japan. ${ }^{2}$

The same, however, cannot be said about Japanese sources about the Christians written in the same period. Many factors account for this imbalance, with the most significant one being the systematic persecution of Christians since

1 Igawa, "The encounter between Europe and Japan".

2 For more information on the jurisdiction of these captains, see Hesselink, "The Capitães Mores of the Japan Voyage: a group portrait". 


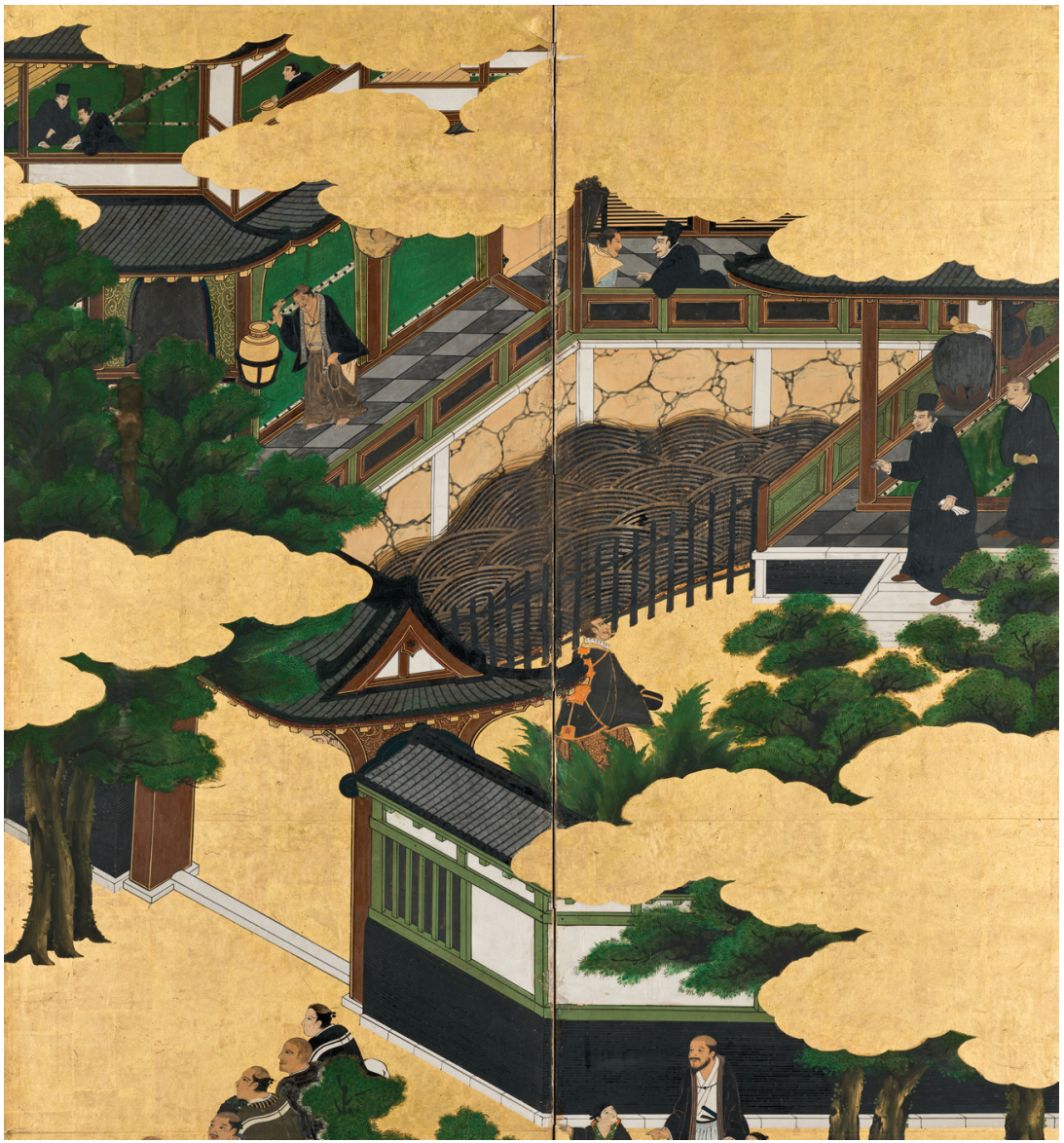

FIGURE 6.1 Namban Folding Screen (Namban Byobu) (excerpt).

COURTESY OF THE MUSEO NACIONAL DE ARTE ANTIGA, PHOTOGRAPHED BY LUISA OLIVEIRA/JOSÉ PAULO RUAS; DIREÇÃO-GERAL DO PATRIMÓNIO CULTURAL / ARQUiVo DE DOCUMENTAÇÃo FOTOGRÁFICA (DGPC/ADF)

the 1580 s in different parts of Japan and, later, in a more general and centralized manner, during the Tokugawa unification, when they had to hide and deny Jesus; professing the Christian faith and preaching became a life-threatening practice. ${ }^{3}$

This chain of events, that occurred in a place far from Europe immersed in a singular political context and the abovementioned inconsistencies regarding sources gathered from Japan and Europe, indicates the complexity involved in studying and writing about missionary history in Japan. Further, such an

3 On the persecution of Christians in Japan, see Ehalt (Chapter 8) in this volume. 
approach is highly challenging as it requires not only multilingual expertise in Japanese, Chinese, Latin, Portuguese, Spanish, and Italian, but also some technical understanding of concepts and ideas from different traditions. Hence, interdisciplinary cooperation is necessary for opening new perspectives in the field. This is particularly true when one looks into intersectional perspectives that consider sexuality, religion, social and economic condition, and status as categories that can be studied in an interrelated manner through the lens of legal history.

Therefore, this chapter proposes that the detailed European descriptions about the life of the Japanese, found in archives in different parts of the world, cannot be studied without looking at what has been developed by Japanese historiographies and interpretations based on Japanese sources. This chapter thus aims to uncover the prolegomena to a legal history of the presence of the Christians in Japan from the 1540 s to the 1630 , from the viewpoint of various normativities found in the practices of marriage among the Japanese.

In this sense, normativity and the making of legal history is understood beyond (and includes) the application of legal instruments commonly attributed to the period of analysis — not only normativities found in the works of missionaries, chroniclers, kings, and captains, but also those present in different Japanese sources and practices of daily life at the time. Taking advantage of methods of comparison developed by global and women's history, this paper compares this documentation in terms of the definitions and descriptions of marriage, its types and classifications, inheritance and kinship systems, divorce matters, and the role of women in society, as understood by missionaries as well as according to Japanese tradition, legal history, and sources.

This chapter is divided into three parts. First, it analyzes the missionaries' sources, particularly those of the Jesuits in Japan, concerning their discussions of Japanese marriage according to the law of nature. This part takes into consideration that religion is an important component of legal history in the early modern period, showing a complex interlayered combination of norms. Religion, manifold as it was, is a source of normative practices. The sources about Japan in the context of the Iberian empires are mostly the product of pragmatic practice and probabilistic thinking of the period; theologians, missionaries, and church officials had to find provisory and more probable solutions for questions about the daily life of Christians, sending letters to priests and theologians with pragmatic content relating to moral theology and canon law. ${ }^{4}$

4 For more on the pragmatic normative production, see Duve "Pragmatic Normative Literature and the Early Modern Iberian Empires in the 16th - 17th Centuries" and Tutino, Uncertainty in Post-Reformation Catholicism. 
The idea of marriage according to the law of nature has been interpreted in various ways in the context of the Iberian empires and was largely discussed in the 16th century in this global arena as it involved the marriage of heathens. ${ }^{5}$ Beyond Japanese marriage, theologians and scholars also wanted to know if the peoples of Africa, Asia, and America, who had been recently integrated into the realms of the Portuguese and Spanish empires, were aware of Christian marriage, because according to canon law, certain peoples did not know the natural institution of marriage, i.e., marriage with the intention of staying together forever and recognizing this as a bond that was only dissoluble by death, instead only participating in transient unions. This was important when validating a previous marriage after a heathen was baptized, so he or she would not live in sin. If the heathens' marriage was considered to have taken place according to the law of nature rather than canon law, it could be validated after their conversion to Christianity. Therefore, it was accepted that marriage could exist in other non-Christianized societies, however, only Christian marriage fulfilled the requirements of divine law. This issue was widely discussed in places like Brazil, China, Mexico City, and Rome. ${ }^{6}$

Second, this chapter introduces the norms of Japan in various periodsduring the Ritsuryō state, the Nara (710-794) and Heian (794-1185) periods, the Kamakura Rule (1185-1333), the Muromachi period, and some of the Sengoku House Laws - as well as further interpretations of different Japanese sources concerning the same issues discussed by missionaries in the 16th and 17th centuries. This paper argues that to understand Japanese marriage and women's legal situation from the 14th century onwards, when women's status and their position in matrimony began to change drastically, it is important to look back throughout the history of Japan to draw a more complete picture of the situation by the time the Christians arrived. This is also crucial for interpreting the inconsistences of the Sengoku period ${ }^{7}$ and highlighting further understandings of the beginning of the Edo period (1603-1868).

The idea to focus on the Christian and Japanese traditions stemmed from the lack of detailed research into the normative background of Japanese marriage according to legal-historical sources from Japan. In general, authors agree

5 For the discussion on the marriage of the heathens in colonial Brazil and the law of nature, see de Castelnau, "Le mariage des infidèles au XVIe siècle".

6 Cruz, Espejo de los Conyuges; Leite, Monumenta Brasiliae.

7 I will use the expression Sengoku period to refer to the years between the Ōnin wars and the siege of Osaka to emphasize the state of war in which Japan was immersed and the political forces and plurality of houses involved in this war. However, I am aware that the expression can be inaccurate due to the historical precision associated to the the Shokuhō period, for example. 
that the familial and matrimonial organizations in 16th-century Japan were structured during the Taika reforms (645) and were reflected in the Taiho legal code. Jesús López Gay, an influential author on the history of Christianity in Japan, for example, used Kirishitan sources and stated that the Yōrō was the code that ruled Japan until this time, connecting these two periods without further explanations of what happened in between. ${ }^{8}$ Following Gay, Haruko Ward emphasized that missionaries were "ignorant about the laws that were in operation in Japan [...], namely the Taihō legal code". ${ }^{9}$ More recently, Hélène Vu Thanh mentioned the Taiho code in a footnote regarding the issue of divorce in her analysis of the topic within Jesuit sources. ${ }^{10}$

Pierre Souyri wrote a piece with a different association; he tried to understand Luís Fróis' second chapter about women, Tratado em que se contêm muito sucinta e abreviadamente algumas contradições e diferenças de costumes entre a gente de Europa e esta província de Japão, by looking at Japanese studies. To expand the understanding of divorce and repudiation in Fróis' Tratado, Souyri relied on a study by Takagi Tadashi on 'Medieval' Japan, mostly about the Kamakura shogunate and the Edo period. On the topic of women's liberty and economic independence in Medieval Japan (Chüsei Nihon or 中世日本), he used ethno-folkloric studies. The importance here is his agreement on the fact that practices from 'ancient' times in Japanese history still influenced the 'modernity'.1 Importantly, consciously or not, these authors did not mention the laws, norms, and practices that existed between these periods, i.e., from the Taihō code until the laws of the Tokugawa shogunate.

8 López Gay, El Matrimonio de los Japoneses. López Gay uses in his analysis of the Yōrō code the translation made by Sansom in the beginning of the 2oth century. This paper also relies on but is not limited to this translation. Recent developments in women's history have pushed forward another interpretation of the translation and adaptations of this code based on the study by Akiko, Ijuin, and Piggott, Gender in the Japanese Administrative Code Part 1.

9 Ward, Women Religious Leaders in Japan's Christian Century, 134.

10 Vu Thanh, quoting indirect sources about the Taihō, says: "In fact, according to the Taihō code from the 8th century, there are seven reasons why a husband may divorce his wife. In principle, a man could not repudiate his wife if she had always been obedient and faithful, or if she had nowhere to go for instance. In practice, the rules were not strictly observed and trivial motives could lead to repudiation". Vu Thanh. "Introducing Tridentine Marriage", 145 .

11 Souyri, "Luís Fróis et l'histoire des femmes japonaises": "A côté des historiens, les ethno-folkloristes ont remarqué la persistance dans les campagnes japonaises jusqu'au debut du XXe siècle de praticques sociales heritées des temps ancient et qui n'ont disparu que sous l'influence répressive de la modernité. Des mots sortis tout droit de l'époque ancienne ou medièvale comme yobai ou utagaki renvoyaient il y a encore peu à une réalité quotidienne dans les zones recilées", 636 . 
By contrast, this chapter offers a new baseline for comparisons through the discourses and descriptions of the European and Japanese. It provides the reader with a more complex picture of the intertwined normativities present in the Christian Century in Japan, to use an expression coined by Charles Boxer. Thus, it demonstrates how a legal history based on Japanese norms can offer information about the description of European sources from the ecclesiastical sphere in the context of a global facet like the Iberian expansion. This chapter argues that although missionaries mentioned little about the Japanese legal tradition behind their descriptions of Japanese marriage, four topics can be highlighted in the sources, whether the documents were from missionaries or the Japanese: the ceremonies and formalities for celebrating marriage that mark the beginning of the act, the number of wives a man could have, the duration of the relationships or the willingness to stay together forever, and the connection between repudiation and divorce.

With this in mind, let us take advantage of the mythological image of Janus as a metaphor: although both faces share the same bust, they can never see each other, unless they use a mirror. But like all mirrors, it would only reflect, never really showing what exists in itself. In the same way, Japanese and Christians could not describe each other by looking into each other's eyes, but as they met, listened to each other's language and voices, and perceived each other's understandings of the world for the first time, the documents they left behind worked just like mirrors: the reports on what they saw were no more than the reproduction of an image because they did not know each other's language, culture, or normative tradition. Each one only exists today due to the description of the other. And, just like the bust of Janus, they cannot be separated. Requests of Missionaries in Japan

"and when [the Japanese were] asked about their intentions, if engaged couples marry with the intention to cohabit until they are dead, almost everyone answered no, only for as long as they are happy".

ALEXANDER VALLA ${ }^{12}$ ambos até la muerte, quasi todos responden que no, sino até quanto fueren contentes". Documenta Indica viI, 35 . 
A few years before the first Jesuit set foot in Japan, Captain Jorge Álvares was already sending Francis Xavier news about these 'new' lands. ${ }^{13}$ According to Álvares, men had only one wife there, and honored and rich people had slaves to serve them. They had their own priests who were responsible for conducting marriages according to a ritual. However, these marriages appeared to be temporary: Japanese men had the habit of repudiating their wives if they considered them to be lazy or bad, often sending them back to their parents if they had children or simply killing them if they were childless. Álvares described women as white, of good proportions, and always worried about the honor of their husbands. In the same letter, he observed that women did all the work at home, like cooking and sewing, and they could go wherever they wanted without having to ask their husbands for authorization. Women were also very clean but lacked modesty: they used to wash all parts of their bodies with their hands, in front of whoever wanted to see. At the same time, he described women as very pious; they had their own house of religion and prayed, as the Portuguese did, using prayer beads. Therefore, women were not all the same: in contrast to the good women who were honored and chaste, there were others who were bad and cunning.

It did not take long for Xavier to see with his own eyes all the events and people that he read about while still in Malacca. In a letter he wrote from Cochin to the Jesuits in Europe, he noted that women had other roles in society beyond being a wife: bomzas [sic.], for instance, were religious nuns. ${ }^{14}$ In 1557 , less than a decade after Xavier's arrival in Japan, Gaspar Vilela, a Jesuit who received permission to preach Christianity from Ashikaga Yoshiteru, the 13th shōgun of the Ashikaga shogunate, described encountering an enormous group of Japanese converts who wanted to be married according to the Christian ritual. At the time, however, Vilela observed that only some of them would be introduced to Christian marriage because not all were as firm in their beliefs for this new faith as to enter into Christian wedlock and follow the Christian precepts. ${ }^{15}$

As mentioned above, the question about the validity of Japanese marriage circulated widely between Europe and Asia, as well as throughout Asia. In 1565, the priest Cosme de Torres wrote from Japan to the general priest of the Jesuit order in Rome musing on the intentions of the Japanese in getting married;

13 Carta de Jorge Álvares a Francisco de Xavier. Malaca, 1546/1547. Documentos del Japón, 1547-1557, 13, §21.

14 Carta de Francisco de Xavier a los jesuitas de Europa. Cochín, 29 de enero de 1552. Documentos del Japón, 1547-1557, 293, §5.

15 Carta de Gaspar Vilela a los jesuitas de Portugal. Hirado, 29 de octubre de 1557. Documentos del Japón, 1547-1557, 692-693, §50. 
they did not seem to be 'internally' convinced of the eternal bond considering that they would separate due to any small incident and marry again with another person. Thus, missionaries needed some guidelines to be able to judge if they could consider such an act as marriage and what they should do in case one of the persons was a Christian. ${ }^{16}$ Similarly, Melchior Carneiro, an apostolic administrator residing in Malacca, received questions or, more accurately, cases of conscience, from the missionaries about the marriage of the heathens in Japan. ${ }^{17}$ In 1567 , he argued that Japanese marriage was not true because they married with the intention of repudiation. It was important, however, that this intention was explicitly expressed in the act. Pragmatic questions from the priests in Japan also reached the capital of the Estado da Índia. Doubts were sent to Goa to be answered by the provincial of India, Antonio de Quadros, and Francisco Rodrigues, the rector of the Colégio de São Paulo in Goa. ${ }^{18}$

On November 9, 1567, the priest Alexander Valla wrote from Malacca to Francisco de Borja, the General of the Society of Jesus in Rome, complaining about the lack of formalities in the ceremony of marriage among the Japanese and asking for advice on what to do. Giving an example, he said that, upon marriage, wives would simply go to the husband's house and stay there for as long as the men wanted. When the men got tired of them, they could send them away and, if repudiated, the women could remarry. But if it was the woman who left the husband, she would need a document from her former husband to remarry..$^{19}$ Repudiation was thus seen by the missionaries as a common practice in Japan, frequent among both women and men, facilitated by the lack of ceremonies involved in the formation of Japanese marriage. ${ }^{20}$

16 "Tambem os casamentos entre os Japoens pareçe que não se obrigão interiormente porque por pequena cousa que pasa entre hum e outro se apartão e casase com outras, e asi dis o marido que não estara mais com sua molher que enquanto le agradar nem a molher con o marido". RASJ, Japonica Sinica, 6 , fols. $4 \mathrm{v}-5$ r.

"Pergunta e reposta do Sr. Bispo D. Melchior Carneiro sobre os cazamentos dos gentios de Japam dada na era de 1567 , em que pareçe foi eleito". BA, Jesuítas na Ásia, Série Miscelâneas, Cód. Ms. 49-VI-6, fol. 85 .

"Preguntas hechas del Japón al P. Francisco Rodrigues, y al P. Antonio de Quadros, provincial de la India toda, que era entonces una sóla provincia”. BA, Jesuítas na Ásia, Série Miscelâneas, Cód. Ms. 49-VI-6, fol. 85v.

19 Documenta Indica VII, 350.

20 "el padre de la mujer manda la hija a la casa del marido, con sus vestidos, y esto se hace sin ninguna ceremonia. Quieren dizir algunos que antigamente se hazían algunas ceremonias, mas se esto es ansí, no se sabe en certo. Y después del marido tener la muger, si le plaze, tiénela y si no, héchala fuera; y las mugeres tanbién, si no se contentan delhos, vanse de las casas de sus maridos. Y en esto ha esta diferencia que, quando los maridos echan las mugeres, puédense casar ellas libremente, com quien quisieren, mas quando elhas se apartan de los maridos, no se caasan, sina ver primero del marido hun escrito 
In their requests for doctrinal clarification, the priests of Japan were mostly concerned about the lack of ceremonies. Could relationships be considered true marriages according to canon law in cases where almost no formalities were observed during the marriage ceremonies and where repudiation was so common? Since the practice of repudiation led to successive marriages, the question also arose as to which of the women was the true wife. ${ }^{21}$ When these questions arrived in Goa, Quadros believed that Japanese men should choose the first wife and, if possible, always return to the first marriage. ${ }^{22}$ Furthermore, the missionaries considered that incest taboos, i.e., the prohibitions of marrying close relatives, did not seem to be well known in this extreme part of Asia. Quadros, for example, struggled with the problems associated with prohibitions of consanguinity in Japanese marriage and, in 1565, asked the Superior General of the Society of Jesus to intervene before the Pope for a general concession of dispensation of power to marry the Japanese despite not meeting the canonical requirements. ${ }^{23}$

Considering that an answer from Rome could take years to arrive in Japan, missionaries kept sending questions to Goa in an attempt to find a solution for their pragmatic issues. A manuscript found in the Torre do Tombo in Lisbon, containing another series of questions sent to Francisco Rodrigues, excellently portrays the way the practices of those times were seen by the missionaries. ${ }^{24}$ Among questions and answers, there are discussions of the sacraments of confession and communion, querying whether they could be ministered to Christians who lived in Japan with non-Christian women or to a Christian woman who lived with a husband who refused to convert. These questions dealt with the issue of disparitas cultus (disparity of worship), and Rodrigues answered

para se pudieren casar, y esto scrito no es sino para evitar algunas discórdias, y no para que sea necessario para el casamiento, porque algunas vezes también se casan sen estos". Documenta Indica VII, 348-350, §§6-8.

On the choice of a wife in case of more than one marriage and the applicability of the Gaudemus in domino in Japan, see: Wirbser, "A Law Too Strict? The Cultural Translation of Catholic Marriage in the Jesuit Mission to Japan".

22 BA, Jesuítas na Ásia, Série Miscelâneas, Cód. Ms. 49-VI-6, fol. 86v.

23 P. Antonius de Quadros S. I., Provincialis, P. Praeposito Generali S. I., Romam. Malaca 20 Novembris 1565. Documenta Indica VI, 496-497, §12.

24 ANTt, "Comentários do Padre Francisco Rodrigues Da Companhia De Jesus sobre os casos versados na Índia e suas partes com muitas outras resoluções mui importantes e necessárias aos confessores, com seu Index de todas as coisas que neste livro se contém. Resposta de alguns cazos que os padres de Japão Mandaram perguntar", Manuscritos da Livraria, $\mathrm{n}^{\mathrm{o}} 8 \mathrm{\circ} 5$, 112. This manuscript has been studied by Lobato, "Notas e Correcções para uma Edição Crítica do Ms. da Livraria N. 805 (IAN/TT)", Pinto and Pires, "The "Resposta que alguns Padres de Japão mandaram perguntar': a clash of strategies?”. 
that sacraments should still be ministered in these cases, in order to encourage the conversion of the heathens. But if one partner still refused to convert to Christianity thereby pushing the other partner away from the doctrine of Christ, he advised that it was safer for them to separate or even remarry. In addition, he agreed that Japanese couples could marry at any time, including during Holy Week.

Rodrigues' comments also noted that virginity was treated differently when compared to Europe: according to the priests, virginity was not an important issue in Japan. Women who had been raped before would neither be considered dishonored, nor incur infamy or injury or lose a good marriage. Priests in Goa believed that this was irrelevant-it should still be treated as the deflowering of a corrupted woman if the woman was not a virgin before it happened. In describing adulterous men of heathen women, as was a common situation in Japan, the same rule was to be applied: the bond between them should never be broken. Finally, in the case of polygamous relations, it seemed that men promised to leave their many wives after baptism into Christianity, albeit without enthusiasm, which made the priests doubt their true intentions.

As the Visitor Alessandro Valignano arrived in Japan in 1579, Rome acquired greater importance in defining how to proceed in these cases. Valignano believed that only Rome should be the one to determine the nature of Japanese marriage. In his writings, he also observed and commented on the propension of the Japanese, as all heathens had, to sins and vices of the flesh. He observed that husbands and relatives killed not only adulterous women, but also the adulterer. Further, the Japanese had as many wives as they desired, although one was considered the principal. The husband could repudiate this principal wife at any time, through a divorce. No family would be offended by this; they would agree on it and even visit each other to talk, probably in reference to political arrangements between families. ${ }^{25}$

In 1582 , Valignano went to Macau, where he attended many meetings to discuss the problems of the mission in Japan, which was now a Vice-Province. In one of these gatherings, he met Alonzo Sánchez, who was temporarily in Macau on a diplomatic mission sent by the governor of the Philippines. They discussed the marriage of the Japanese and Sánchez, a connoisseur of the situation of the mission in Mexico, Philippines, Macau, and (less in) Japan, stated that the marriage of the heathens could not be solved in different places using the same solution; different solutions should be chosen for each single situation. ${ }^{26}$ The outcome of this meeting acknowledged that there was no such thing as a true concept of marriage among the Japanese.

25 Valignano, Sumario de las Cosas de Japon.

26 López Gay, El Matrimonio de los Japoneses. 
A decade later, in 1592, the priests in Japan organized with Valignano the First Provincial Congregation of Japan in Nagasaki. ${ }^{27}$ They decided that questions about Japanese marriage should be sent directly to Rome. For this purpose, Gil de la Mata was elected as the mission's Procurator and sent by Valignano to Rome, where he arrived in 1594 to report on the progress and difficulties of the Jesuits in Japan to the general of the Society of Jesus. Valignano was firm in his attempts to make direct contact with Rome avoiding the passage through Goa. He proposed two solutions to be taken to Rome by Mata. First, he asked the Pope to declare that Japanese marriages were not valid. Second, if the Pope was against this first solution, it was necessary to, at least, dissimulate Japanese marriage. ${ }^{28}$

Besides having to come back with a definitive solution from the Pope, Mata was also responsible for reporting these cases of the Japanese mission to universities in Europe. Therefore, before reaching Rome, he stayed in (what is today) Spain where he was in touch with priest Gabriel Vázquez, professor at the University of Alcalá, with whom he discussed the moral problems of the mission in Japan. Questioned about Japanese marriage, Vázquez answered that he did not believe in its validity, since the Japanese presupposed repudiation of the wives when getting married. Nevertheless, the solution was more complex than this, ${ }^{29}$ thus, he considered it a special case compared to other heathen peoples. ${ }^{30}$ Therefore, the distinction between those who could or could not follow Christian doctrine inside wedlock and the discussion about whether the Japanese could understand the responsibility and sacramentality of Christian marriage reached European universities.

27 The complete text of the discussions can be found in Valignano, Adiciones del Sumario de Japon, Primeira Congregación de Japón, Apendice III, 677.

28 On the concept and discussion of dissimulation, Zagorin says that "the practice of dissimulation as it has been rationalized and justified by theologians, casuists, philosophers, and political theorists [...] is a distinct and profoundly important historical phenomenon that is especially related to politics and, even more, to the persecution by states and churches of heretical and minority religious bodies and heterodox and dangerous ideas. In the case of those who are victims of either religious or intellectual intolerance, dissimulation is also associated with clandestinity, the maintenance of an underground existence, and esotericism. In this second form, it played a major role in the religious and intellectual life of Western Europe in the sixteenth and seventeenth centuries, not to speak of its antecedents in the Middle Ages and its persistence to a certain extent during the Enlightenment". See Zagorin, Ways of Lying, 2.

29 See "Respuestas del Padre Vazquez a varios casos, que de japon preguntaron los nuestros, los cuales truxo el Padre Gil de la Mata procurador de Japón. Difficiliores casus, quorum resolutio in japonia desideratur, et primo circa matrimonia", in López Gay, "Un Documento Inédito del P.G. Vázquez (1549-1604) sobre los Problemas Morales del Japón”. 
Mata came back to Japan in 1598 and died a year later in a shipwreck on his return to Europe as procurator of the Vice-Province of Japan. Before these events, he wrote his own treaty defending Japanese marriage, De Japponiensum Matrimonio, where he came to an understanding of it through three approaches. First, he acknowledged those young people who were forced to marry by their parents. Here, the marriage was clearly not valid. Second, he noted the marriages that happened according to the couple's wishes but could be dissolved at any time if they did not go well. Third, there were those agreed upon without any special intention of maintaining them. According to him, the Japanese were somewhat aware of the true idea of marriage. However, they had false ideas about its characterization. Furthermore, he was also interested in differentiating marriages from concubinates. ${ }^{31}$

Another document from 1585 written by Jesuit missionary Fróis, compared women from Japan and women from 'Europe' (povos da Europa). In his comparative treaty, Fróis argued that women from Europe took care of their honor and modesty, while Japanese women did not care about virginity, since they did not have honor, and freely showed their arms and breasts. While in Europe husband and wife shared the conjugal patrimony, which belonged to the couple, in Japan each one possessed it separately after the marriage. In Europe, men did not repudiate women; in Japan they did so whenever they wanted without women losing their honor or marriage because of it. On the contrary, sometimes women even repudiated men. Further, abortion, which was not so frequent in Europe, was common in Japan with some women having it done more than 20 times. The killing of children was also frequently committed even when maintaining the children was possible. While European women were enclosed at home and needed authorization from the husband to come and go, in Japan they were used to going wherever they wanted without the need for authorization. Even religious women in Japan, Bikunin (比丘尼ん), lived in open places (that looked like houses of prostitution), while in Europe they lived in confinement. Japanese women were also encouraged to receive education and they rode horses, just like men. Fróis also argued that in Europe, women cooked, and men were tailors, whereas in Japan it was the opposite. ${ }^{32}$

Recently discovered documents are making it possible to deepen the discussion of the application of even more complex norms according to the Council of Trent, held between 1545 and 1563, by the missionaries in Japan. Considering the importance of the new rules decided by the Council for the celebration and recognition of marriage, the discussion of their application is highly valuable

$31 \quad$ López Gay, El Matrimonio de los Japoneses.

32 Fróis, Tratado em que se contem muito suscinta e abreviadamente algumas contradições e diferenças de costumes entre a gente de Europa e esta província de Japão, cap. 2, 119-136. 
for understanding marriage practices in Japan during the Christian Century. ${ }^{33}$ Although since October 7,1565 , Pius v established the mandatory application of the Council in the 'Orient' with the papal brief Pervenisse ad te litteras, ${ }^{34}$ it was difficult to maintain the mission in Japan and to follow the specific rites established in Trent because of the persecution of Christianity, which was systematically more organized since the $158 \mathrm{os}$. As it begins by addressing the lack of answers received from Rome, the Cassos Resueltos en Goa pro los Padres de la Companhia cerca del ministério de Japon, recently discovered in Manila, ${ }^{35}$ proves that the priests in Japan were still caught up in these pragmatic problems facing the Japan mission. ${ }^{36}$ This information proves that the theologians in Goa were indeed addressing these matters and that Rome was not sending answers.

The Cassos manuscript brings together the missionaries' struggles concerning controversial themes within their evangelization, such as usury, slavery, and idolatry. But, primarily, a huge part is dedicated to the validity of Japanese marriage. The priests argued that, despite the custom of repudiation, marriage among the Japanese was true and could not be dissolved. The consequence of this recognition was that the Japanese, after becoming Christians, could only have one wife, who they could choose, and were not allowed to take another. Even if they did not marry according to Trent, but according to the customs of the Gentiles (costumbre de los gentiles), the act would be considered not only a contract, but also a true marriage.

The document reveals yet more details. The Japanese had the custom of making strong promises of marriage among themselves and for their children which, according to ancient custom, as written in the document, or simple obligation, were kept although, at the time of the marriage, they no longer wished to keep them. Thus, marrying only to keep the promise, they repudiated the spouse one or two months after the marriage.

The priests in Goa insisted on the publication of the decisions of the Council with some guidance. First, during the sermons, the priests should emphasize the importance of the sacrament of marriage. Second, the priests should advise everyone to marry following the prescriptions of Rome, and those who were not married accordingly should nevertheless keep their marriages and never repudiate their wives. Third, the publication of the rules from Trent should be

33 Reynolds, How Marriage Became One of the Sacraments.

34 Magnino, Pontificia Nipponica, 7 .

35 Ehalt, "Goa no Iezusukai Shingakusha to Nihon no Doreika Mondai" and Ehalt, "Casuística nos Trópicos”.

36 "Aun que la verdadera resolucion de muchos cassos de Japon sea de esperar de Roma despues q fueron embiados a su Sanctidade [...]". AUst, Varios Tratados Manuscritos y Varias Consultas. Siglo XVII. 
delayed by one month, and only after that could it be declared that married couples who did not follow the specific norm of marrying with a priest and testimonials would be treated as amancebados (cohabiting) and not married.

From these sources and the information they offer concerning the marriage practices of the Japanese, it can be highlighted that, although the Christian marriage procedure is clearly defined, someone can only infer, from these missionaries' observations, what Japanese marriage meant according to Japanese peoples' own sources and normative system. So, where and how can someone find another way to tell this story? To open new paths in this direction, the following section studies what it meant to marry according to the Japanese normative system, taking advantage of the fact that many Japanese sources from the period before the arrival of the Christians are known, which unfortunately is not the case for other places under influence of the Iberian empires in the early modern period.

Japanese legal history is strongly influenced by the Chinese codes from the Sui and Tang dynasties. During the late 7 th and early 8th centuries, under the influence of the Taika reforms, the Japanese 'state' compiled and promulgated the Ritsu and the Ryō, two books that contained a series of norms based on Chinese sources, also known as the Ritsuryo. These codes were in force for centuries and influenced centuries of legal production in Japan, determining the features of legal systems of different historical periods.

However, as will be discussed in this section, more recent historiographical studies, highly influenced by women's history, have shown that the letter of the law had little importance when analyzing what happened in people's daily lives - particularly regarding normative practices. This is not only due to previous Japanese normative practices, but also because of a long process of translation of and comments on the codes which took place in the centuries following the Taika reforms. Therefore, the production of normative knowledge in such contexts can be considered as an ongoing process that involved interpreters who added new features according to local practices and particular epistemic traditions. ${ }^{37}$ This section explores how practices concerning Japanese marriage often went beyond the letter of the law, even after the promulgation of the Ritsuryo.

37 Duve "Pragmatic Normative Literature and the Early Modern Iberian Empires in the 16th -17 th Centuries". 


\subsection{Marriage Norms in the Ritsuryō Tradition}

The Ritsuryō was divided in two books. The Ritsu was the code of criminal matters, including prohibitions and punishments; the Ryō prescribed administrative norms, functions of the department of state, and duties of officials. The first versions of these books have not survived, including that which was promulgated by emperor Tenji (Tenji-tennō) in 662. The version of the Ritsuryō we know today is the Yōrō code, enacted in 718 but promulgated in 757 , which is an updated version of the Taihō code of $701 .^{38}$ These books remained in effect until they were formally abolished in the early Meiji period in the late 19th century.

The specific norms of the domestic sphere and household, the Law on Residence Units (Ko or 戸), were addressed in section 8 of the Yōrō code, and divided into 45 clauses. $^{39}$ A Ko consisted of a residence unit head (Koshu or 戸主) and 20 to 30 members while a group of 50 Ko would form a Sato (里). The term Ko has had many translations through time and there is still no scholarly consensus on its definition. ${ }^{40}$ This section of the Yōrō code established the norms for household registers (Koseki or 戸籍), taxation of the population, and preparation of provincial population registries. ${ }^{41}$ But, most importantly, this section also included norms regarding the organization, administration, and control of the $K o$, the norms regarding marriage and family structure, and the regulation of the status of the people.

In the clauses of the Yōrō code there are various norms on household, as well as rules that regulated marriage, inheritance, divorce, and lineage. Marriage, according to the code, meant the wife moving to the husband's house. The term used for marriage in the Ritsuryō (clause 24) is Konka (婚家), referring to a man taking a wife (Kon 婚) and a woman entering her husband's

38 Inoue, Ritsuryō.

39 The Yōrō Laws on Residential Units are included in Inoue, Ritsuryō. Translation can be found in Sansom, Early Japanese law and administration, vols. 9 and 11. For a more detailed analysis, transcription, and precise translation, see Yoshie, Ijuin, and Piggott, Gender in the Japanese Administrative Code Part 1.

40 Yoshie, Ijuin, and Piggott highlight the definitions made by several scholars, such as Whitney Hall ( $K o$ as natural communities and local residential groups inspired by the family organization), Conrad Totman (Ko as statutory households), and Carl Steenstrup (Ko as artificial extended families). However, they choose to "follow the consensus in recent research by avoiding such terms as 'household' and 'family', while emphasizing the statutory quality of this 'residence unit'. See Yoshie, Ijuin, and Piggott, Gender in the Japanese Administrative Code Part 1, 99 .

41 Some of the records have survived and have been archived in the Shōsōin (正倉院), the storehouse located at the Tōda-ji in Nara (東大寺). They were included in the Dai Nihon komonjo (大日本古文) shōsōin monjo, vols. 1 and 24. 
household ( $K a$ 家). The norms compiled in the 7 th and 8th centuries had a strict distinction between wives and concubines, specifying, among other things, that a man could have only one wife while placing no restriction on the number of concubines he could have. ${ }^{42}$ The status of women concerning conjugal relations was particularly relevant for their social roles, as can be seen by the language and distinctions used in the period. ${ }^{43}$ The notion of illicit sexual intercourse also found a place among these norms: if intercourse took place before the marriage, including all unions with concubines, the marriage was to be dissolved. ${ }^{44}$ Divorce was only a possibility for ending relationships when initiated by the man, and only in certain circumstances. ${ }^{45}$

Beyond the letter of the law, there is still much more to discover about marriage practices in Japan under the influence of the Ritsuryō. Even though the Yōrō code became central for the newly created Ritsuryō state, it is not the only source for understanding the normative practices that influenced Japanese marriage and the constitution of the household. Sources for the legal history of Ritsuryō Japan also include, for example, commentaries on these laws, such as the Ryō no Gige (令義解) (833) ${ }^{46}$ and the Ryō no Shuge (令集解), ${ }^{47}$ both attempts to adapt Chinese laws to Japanese society, giving them meaning, significance, and applicability. Among these commentaries, it is also possible to include the Procedures of the Engi Era, the Engi-Shiki (延喜式), completed around 927. These are a collection of 50 volumes on norms and customs concerning how to better implement the codes from China in Japan, regarding essential regulations for carrying out the day-to-day details of civil and religious administration and requirements for holding office. They represent a body of regulations designed to supplement the administrative code that was drawn up in the early 8 th century. 48

42 Clause 23, for example, allowed inheritance to be shared between children from wives and children from concubines.

43 See Yoshie, Ijuin, and Piggott, Gender in the Japanese Administrative Code Part 1.

44 Hossō shiyōshō. The original text from the Ritsuryō regarding consensual sex or adultery, Wakan (和姦), and rape, Gōkan (強姦), has been lost, but some parts survived among quotes found in the Hossō Shiyōshō (法曹至要鈔), a legal commentary dating from the late-Heian or early-Kamakura periods. Also see Goodwin, Selling Songs and Smiles, and Goodwin, "Shadows of Transgression: Heian and Kamakura Constructions of Prostitution". For example, according to Clause 28 , if the wife did not bear a male child; if she had committed adultery or was promiscuous; if she disobeyed her parents-in-law; if she talked too much; if she stole something; if she was jealous; or if she had a serious disease. "Ryō no Gige", in Shintei zōho kokushi taikei, XxII, 348-350.

47 "Ryō no Shuge", in Shintei zōho kokushi taikei, xxıv.

48 The first ten books were translated in Engi-shiki, books I-V and VI-X. Norito, the 8th book about the rituals, is also translated in Norito. 
Other sources have also been taken into consideration by recent historiography, such as collections of poems like Man'yōshu (万葉集) ${ }^{49}$ from the 8th century; archeological findings such as Mokkan (木簡) 50 and Setsuwas (説話); or tales of the period that recount the lives of the common people. The latter was an East Asian literary genre that consisted of myths, legends, folktales, and anecdotes, such as the Nihon Ryöiki (日本霊異記), written between 787 and $824 .{ }^{51}$

These sources and recent studies have highlighted that the norms of the Ritsuryō polity, in the Chinese format, were not strictly applied to Japan. Gradual transformations and adaptations from China took place in the archipelago, creating a system that better fit the social and economic situation of Japan. These discussions prove that the importation of the Chinese codes did not represent the mere implementation of foreign written laws, but rather were the object of scholarly discussions and social adaptations. Some specific themes illustrate these adaptations. Issues such as family and household, lineage patterns, inheritance, and divorce, as well as religion and the social role of nuns ${ }^{52}$ and the sex trade ${ }^{53}$ appear in these sources and provide a complementary way of understanding what happened in the period.

For example, the household statute, the Koryō (戸令), that survived in the Ryō no Shüge and Ryō no Gige, has references to marriage. Illicit sexual relations were difficult to prove in Japan because marriage usually began with voluntary sexual relations between the couple. In practice, the authorization to marry in Japan seemed to be up to the man and woman and, only then, were the parents consulted. Likewise, the residence unit (Ko), as it was organized in China, cannot be confused with a family group in Japan where, unlike China, different marriage arrangements were possible. Therefore, since the Nara period at the latest, wedding ceremonies were not clearly defined, and the easy possibility of a divorce made it even more difficult to clearly define the type of relation a couple had. Thus, marriage was not formalized by an elaborate ceremony, but rather by a fluid protocol that changed from one period to the next. ${ }^{54}$

49 Translation: The Ten Thousand Leaves.

50 Piggott, "Keeping Up with the Past. New Discoveries Enrich Our Views of History" and Piggott, "Mokkan. Wooden Documents from the Nara Period".

Translation: Miraculous Stories from the Japanese Buddhist Tradition: The Nihon Ryōiki of the Monk Kyōkai.

Meeks, "Buddhist Renunciation and the Female Life Cycle". In the Yōrō code, there was a special section with 27 clauses regulating Buddhist monks (sō) and nuns (ni). See The Yōrō Ritsuryō Sōniryō. Laws on Monks and Nuns.

53 Goodwin, Selling Songs and Smiles.

54 Wakita, "Marriage and Property in Premodern Japan from the Perspective of Women's History". 
Related to the concept of $K o$, it is important to discuss the Ie (家), another central and controversial institution in the history of Japan which has characterized the constitution of families. In the 7 th century, since the residence was not yet an independent unit of production, the Ie could have at least three different meanings: a unit made up of a mother, father, and child; a unit of production including residence and storehouses (also called Yake or Yaka 宅55); or a patrilineage transmitted from father to son or heir, or, more controversially, from mother to sons and daughters. At this time, only the first option existed for commoners; but, in the late 8th century and early gth century, some commoners were already creating households that were also units of production. ${ }^{56}$

This unstable definition is due to the fact that the Ie changed many times in Japanese history and was the outgrowth of an earlier institution, the $U j i$ (氏), which dated to before the Taika reforms in the 7 th century. Today, the word is still used in the Japanese language, though not in the same sense as it was used in the Sengoku, Edo, and Meiji periods, when it acquired its more modern features. 57

For now, it is important to observe and understand how the Ie connected and influenced the inheritance systems of Japanese society and, hence, also the marriage system. In Japan during the period of the implementation of the

55 Before the codes, the Chinese character for Ie was read as Yake or Yaka and used to refer to a storehouse or similar structure. See Shiro, Beyond Paradoxology.

56 Yoshie, Ijuin, and Piggott, Gender in the Japanese Administrative Code Part 1.

57 The discussion of the $U j i$ and the Ie deserves much more attention than is possible to address in this chapter. While McCullough writes that the $U j i$ and the $I e$ in Heian times would mean a $U j i$ closer to the concept of a clan (a patrilineal institution whose members bore a common name, worshipped common deities, had common properties, claimed on descendancy, and were buried together), the Ie is considered a co-residential family/ household in which the female line is respected. Shiro Ishii deepens the discussion in his work. According to him, the thesis of Yoshida Takashi defended that the Japanese state sought to establish a ruling class (great noble families who had been granted Ie) of blood-lineage groups whose leadership would be unilaterally hereditary, passing from father to son, and this new type of blood-lineage group was given the name of $I e$ in imitation of the Chinese model. As a result, the way in which the word Ie was used also changed. It no longer referred to a building of a facility (the storehouse) but was used to allude to organization and blood-lineage groups, and the pronunciation Ie began to be used consistently for the reading of the kanji from this time. It would take another 200 years before the consolidation of the $I e$ as it was recognized in later periods of Japanese history. Ishii defends the thesis that the $I e$ is a group that existed to serve a higher-ranking ruler, ultimately, the emperor. A corollary to this is that the emperor had no Ie and no Ie name. The prototype for this Ie was the sekkan-ke forerunners and Ie of nobility that were formed after the 11th century and became a universal institution in Japanese society. See Shiro, Beyond Paradoxology. 
Yōrō, it was not yet customary to inherit from a spouse. Instead, inheritance was typically passed on from parent to child or from one $U j i$ head to the next. Women as well as men participated in this process; female holders of property frequently appear in records of land sales and purchases. ${ }^{58}$ Thus, beyond the Chinese-influenced written law, other sources indicate that the management of the household until the late 8th and 9 th centuries could be exercised either by a man or a woman, or even collaboratively. ${ }^{59}$

From this perspective, more historians are questioning the straightforward application of the Ritsuryō law, which foresaw patrilineal transmission of property and the house registry system required families to register in the name of the male head of the household. ${ }^{60}$ This may have been only a fictional narrative overlaid on top of a still-matrilineal society or, at least, a society that allowed both male and female participation in household decisions. Therefore, scholars are increasingly concluding that the social systems of China and Japan were essentially different in various aspects. During the imperial governance (Asuka, Nara, and Heian periods) Japan did not have a patrilineal lineage like that in China, where patriarchal and patrilineal families were the rule. Instead, it is considered a bilateral or bilinear descent society, where both sides were important for the lineage because family structures and marriage types were much more fluid. Sons and daughters could claim lineage belonging to the father, the mother, or to both. But to understand the practice, one must look at the kind of marriage that was practiced in Japan in the 8th century.

\subsection{Household, Inheritance, and Marriage in Japanese Women's History}

Moving beyond the legalist approach to the codes, women's history in Japan has helped track the complexity of marriage arrangements and types, as well as details on the sexual behavior of the Japanese. ${ }^{61}$ The political roles of women in the history of Japan have been questioned and new interpretations of the sources highlight a more complex scenario concerning how social and economic standings changed through time.

58 Yoshie, "Gender in Early Classical Japan".

59 Sekiguchi, analyzing the Man'yōshu, for instance, defended that the terms heirs and nonheirs were borrowed from China and existed only in the codes. In practice, the patrilineal succession had not been established yet. See Sekiguchi, "The Patriarchal Family Paradigm in Eighth-Century Japan".

6o Wakita, "Marriage and Property in Premodern Japan from the Perspective of Women's History".

61 In Japanese, women's history ( joseishi or 女性史) and gender history ( jendāshi ジェンダ 一史). For more, see Noriyo Hayakawa, “The Development of Women's History in Japan” and Hitomi, "Family, women, and gender in medieval society". 
Although the Yōrō referred to the Chinese patriarchal organization-where a bride was brought to the family of the husband - there are indications that dispositions of the code were not wholly representative of how certain relations were practiced. This was already addressed by Asakawa in the early zoth century: "the custom, already outgrown by some people but still in evidence with many at the beginning of history, of the husband and his wives all living apart from one another". ${ }^{6}$

In the 1930s, Takamure Itsue began to trace the lines of the first modern aspect of women's history in Japan. She chose to focus on the changes undergone in the marriage system from uxorilocal to virilocal marriages, interpreting it as the major factor in the decline of women's status during what was considered by the historiography of the time as 'medieval' Japan. Her innovative ideas were based on the argument that marriage and family relations differed drastically from period to period, alongside which she developed a system based on three types of marriage: Tsumadoikon (妻問い婚), Mukotorikon (婿取り婚), and Yometorikon (嫁取り婚). The first, which prevailed until the late Nara period, was also known as duolocal or visiting marriage, in which the couple did not live together, but belonged to two different households, with the husband visiting the wife. ${ }^{63}$ In the second, common in the Heian period, the husbands lived with their wives. In the third, standard during the Muromachi period, the wife was taken into the husband's family.

William McCullough's pioneer work in the 196os on Japanese marriage institutions in the Heian period, although extremely focused on high-class women in Kyoto, suggested that marriage did not involve a clear move of the wife to the house of the husband. Many more manifold arrangements were possible at that time, revealing even more types of marital residential models. Duolocal residence, where husband and wife lived in separated residences, was as common as uxorilocal unions, when the man moved into the residence of the wife's parents, becoming part of her family; and even virilocal marriages, when the woman lived with the man's family, existed. ${ }^{64}$ There were also neolocal marriages, when man and woman lived together apart from their in-laws. Strikingly, McCullough agreed with Takamure: he found no virilocal (or patrilocal) marriage in the 12th century. This affirmation means that the conjugal tie as

\footnotetext{
62 Asakawa, The early institutional life of Japan, 57.

63 This marriage was different from the one established in Clause 24 of the Ritsuryō. While the expression konka made explicit reference to Chinese virilocal marriage, the type of marriage where the wife moved to the husband's house, we can observe that this was not the general model practiced in Japan, where the term simply meant 'to marry'. See Yoshie, Ijuin, and Piggott, Gender in the Japanese Administrative Code Part 1.

64 McCullough, "Japanese Marriage Customs in the Heian Period".
} 
forming an independent unit did not happen in Japan in the early centuries; family was not a coherent institution, which is why the legal category of Onna, the reading of the character 女 in Japanese for woman, did not imply any marital status, because a married woman could still be in the house of her family.

Wakita Haruko questioned Takamure's and McCullough's classifications in the 199os, while also contesting another writer of women's history in Japan, Inoue Kiyoshi, ${ }^{65}$ who only looked at women of the lower 'classes' who lacked status and property. ${ }^{66}$ For Wakita, in the Nara and Heian periods women and men enjoyed relative equality in marriage, along with property rights and membership in the village communal organization, such as community religious rituals. Uxorilocal marriages predominated among aristocracy. But there were also duolocal marriages in the Heian period: the couple lived separately and children stayed with the wife. ${ }^{67}$ Wakita proposed additional classifications for the different marital arrangements in the Heian period: the Boshokon, where the mother's wife's residence was central for the marriage; Tsumadoikon, where the husband visited the wife but lived in another place; Mukotorikon, where the son-in-law was adopted by the wife's family; Shōseikon (招婿婚), where the husband was invited to the wife's residence; Yometorikon, where the husband took the wife into his family; and Dōkyo (同居), when the couple lived together.

Therefore, women developed different roles in society beyond that of being 'merely' a wife. Women could exercise many social and economic roles in Nara and Heian Japan. For example, women of powerful families engaged in moneylending, ${ }^{68}$ production and sale of sake and storage of rice, and, among those of yet higher status, managing productive enterprises in their independent residences, thus playing a major role in society. ${ }^{69}$ Women performed the greater portion of work in the $Z a$ (座), commercial organizations like guilds, where knowledge was passed from mother to daughter. Among higher social positions, in the aristocratic world, men and women participated in state politics as officials, working together to support the emperor's private life. Aristocratic women worked at the courts and had their own economic independence, like ladies-in-waiting who served in powerful noble families. Serving at court was the most widespread social occupation for noblewomen, whose work entailed

\footnotetext{
65 Inoue, Nihon joseishi.

66 See Wakita, Women in Medieval Japan. Motherhood, Household Management and Sexuality.

67 Wakita, "Marriage and Property in Premodern Japan from the Perspective of Women's History".

68 See Gay, The moneylenders of late medieval Kyoto.

69 Wakita, "Marriage and Property in Premodern Japan from the Perspective of Women's History".
} 
the political and economic aspects of the organizations of the great families. Women also worked as entertainers, artists, and prostitutes, occupations that have received some attention in research on sexualities and women's history in Japan..$^{70}$

However, when the power of the emperor diminished due to the rise of the Kamakura shogunate, the complex family system changed again, this time to the new medieval $I e$ in Japan, described above. Moreover, the beginning of the 11th century is associated with the establishment of the Ie and the spread of the practice of Yometori(kon) marriages among commoners and the feudal classes. All institutions and occupations, including political and economic structures and agriculture, were based on the institution of the $I e$ which, in this period, changed to a patriarchal unit with one husband and one wife where the wife came to live with her husband. ${ }^{71}$

This change had to do with the manorial system of land control, the Shōen (荘園) and the Sōryō (少領) system. If in Heian Japan elite women's property rights were guaranteed in the form of land, residence, and movable goods, in the Kamakura shogunate land rights passed through a process of change because of the militarization of Japan and the rise of a warrior aristocracy. For example, vassal-lord relationships were based on the vassal's promise of civil, military, and financial obligations, with the lord in return pledging protection. Inheritance and kinship ties were transformed to strengthen the property by naming only one heir and to unify the family under the head of the house. ${ }^{72}$

Nevertheless, this process varied from family to family. ${ }^{73}$ The practice of primogeniture was gradually adopted and can only be understood in the context of the land division system because the family unit was in control of the land and the production of goods and the warrior houses needed to find ways to perpetuate their lineage while, at the same time, guaranteeing the survival of its members. The oldest son received the largest share of the estate and exercised control over the property of all family members, aligning closer with the Chinese system of imperial organization. ${ }^{74}$ As virilocal marriage became more

70 Wakita, Women in Medieval Japan. Motherhood, Household Management and Sexuality and Yoshie, Ijuin, and Piggott, Gender in the Japanese Administrative Code: Laws on Officials in the Back Palace (1).

$71 \quad$ Wakita and Philips, "Women and the Creation of the 'Ie' in Japan".

72 Mass, Lordship and Inheritance in Early Medieval Japan.

73 Hitomi, "Family, women, and gender in medieval society" mentioned various cases of daughters and wives and widows that still inherit in the first half of the Kamakura shogunate.

74 This chapter dedicates little space to the changing system of division and ownership of land and the distribution and utilization of Japanese soil, but the issue is fundamental to understanding inheritance patterns since the Kamakura shogunate. For more on the 
and more common, the warrior family unit based on the Sōryō system inflated the power of the head and his leadership over the extended family. Inheritance rules depended on the children the couple had..$^{75}$

To secure the new regime, a new written norm was reinforced in the 13th century. The Formulary of Adjudications, Jōei Shikimoku (貞永式目) or Goseibai Shikimoku (御成敗式目), was the legal code of the Kamakura shogunate in Japan, promulgated by the third shikken, Hōjō Yasutoki, in 1232. This new law expected to create a new society for a new era, which was to be governed by the warrior class and their lords, the daimyōs. In this specific law, there were some articles that dealt with Japanese marriage and the modification and transformation of the inheritance system. In cases of serious crimes (treason, murder and maiming, dacoit, piracy, night attacks, robbery), the guilt of the husband was extended to the wife. ${ }^{76}$

In cases of divorce, whether the woman was a wife or concubine, after the husband filed for divorce, there was the possibility that the woman could retain the tenure of the fief of her former husband. If she had a virtuous record and was innocent of any fault, simply having been discarded by reason of the husband's preference for novelty, her fief could not be revoked. However, if the wife had been repudiated, it was possible that she might not retain the fief. ${ }^{77}$

Women could adopt heirs-a legal novelty introduced during this time. Although the spirit of previous laws did not allow adoption by females, the practice was well known and widespread in both cities and rural areas, again pointing to the little pragmatic effect the legal codes had. Thus, women who had no children of their own could adopt an heir and guarantee her line of succession..$^{78}$ The relevant article shows that the separation of the lines of succession between man and woman, husband and wife, was theoretically still in force by the beginning of the government of the Kamakura shogunate, but would not last until the end of the Kamakura Bakufu (or 幕府, another word for the rule of the shogunate). Furthermore, documents analyzed by Hitomi Tonomura show that women were not only adopting mothers as heirs but were also adoptees. ${ }^{79}$

subject, see Mass, Lordship and inheritance in Early Medieval Japan and Hitomi, "Re-envisioning Women in the Post-Kamakura Age".

Wakita, "Marriage and Property in Premodern Japan from the Perspective of Women's History".

76 Hall, Japanese Feudal Law, art. 11.

77 Hall, Japanese Feudal Law, 197, art. 21.

78 Hall, Japanese Feudal Law, art. 23.

79 Hitomi, "Family, women, and gender in medieval society". For the translation of other disputes and wills, see Mass, Lordship and Inheritance in Early Medieval Japan. 
Widows who had succeeded in retaining the fief of their deceased husbands had to give up any personal projects and devote themselves to their husbands' legacy. If they disagreed and wished to marry again, the fief held by their late husband was to be granted to the husband's son. ${ }^{80}$ This article was modified seven years later: it seems that some widows were transferring the late husband's land to their chosen heirs before marrying again. The Bakufu changed the article, limiting the alienation to be made at deathbed only. ${ }^{81}$ This information implicitly indicates that, at this time, women were already inheriting from men.

Article 34 differentiates between women's sexual relations, such as rape and adultery: rape was a subcategory of $\mathrm{Kan}^{82}$ or violation, while $G \bar{o} k a n$ (強姦) was illicit coercive violation. Adultery, Wakan (和茹), involved illicit and consensual violation. ${ }^{83}$ This article is different from the one in the Ritsuryō, in which man and woman were considered equal in questions of adultery involving consensual relations. A man who committed adultery, regardless of whether the act was rape or not, would be deprived of half of his fief. If he had no assets, he would be exiled. However, although the norm differentiated rape from adultery, it foresaw only one punishment for both cases. A woman who committed adultery or was raped was to be deprived of her fief. If she had none, she would also be exiled.

These articles dealt with the administration of inheritance of the head of the $I e$, the man, and the division of the property between the children and the wife. Each warrior family needed to maintain consistency and continuity in their specific jurisdiction and territory. Thus, now connected to the land and the protection of the warrior class and daimyōs, it was important to concentrate the lineage and inheritance in a single heir, disregarding brothers and sisters, in order to maintain the family and the Ie. The practical solution solidified over time: inheritance would be unitary, excluding younger siblings.

From this point on, women's property, which was clearly independent of the husband, was subordinated to the family unit and the man of the house. In addition, from the 1oth and 11th centuries, women were gradually denied membership rights to local communal organizations (Kyōdōtai, 共同体) and

8o Hall, Japanese Feudal Law, art. 24.

81 Hitomi, "Family, women, and gender in medieval society".

82 The term most used for sexual violation is 姦 or 奸, usually pronounced kan in combination with other characters, but also read midare, midasu, and okasu. Another term for sexual violation is 淫 (pronounced in). In Heian sources, this is sometimes used to indicate licentiousness, rather than a specific offense, and is often applied to women. Entries from the 8th-century chronicle Nihon shoki show that both men and women could be punished for sexual violations. See Goodwin, Selling Songs and Smiles, 46 . 
were prohibited from doing specific work, instead assuming auxiliary roles as the wives of community members. ${ }^{84}$

However, Wakita defends that Yometori marriages, typical in Japan from the 11th and 12th centuries, did not cause an absolute lowering in the status of women. While husbands took on a patriarchal position as head of household, the official wife was guaranteed social status and rights in a secure position. ${ }^{85}$ Particularly among the marriages of commoners who had no assets, both partners would take up joint residency and have equal status. Again, Wakita points to the need of analyzing the sources according to status, nobility, social position, and gender.

According to her, women had responsibilities and, as official wives and mistresses of the house, they managed the Ie of the medieval period together with the husband. Although women were second in command, their authority was as strong as their husband's. The responsibilities of the wife of a warrior, for instance, were not only focused on the acquisition and preparation of food and clothing, but also involved managing the budget, selling tributary items, purchasing provisions, maintaining weapons and armors, and looking after subordinate members of the household, such as servants.

More recently, however, Hitomi Tonomura showed that by the second half of the Kamakura shogunate, the perpetuation of the Ie was conditioned to a vertical transmission of inheritance and lineage, rendering women peripheral; they were only reproductive vehicles and pieces to be exchanged in the forging of alliances. ${ }^{86}$ As family organization and inheritance practices had changed by the end of the Bakufu, women publicly became vassals to their husbands and owed them a higher degree of obedience. Therefore, during the 14th century, women were excluded from membership in local organizations, marriages became exclusively virilocal, and women began, as a rule of thumb, to live with the husband's family to guarantee the maintenance of property and patrilineal lineage and inheritance. ${ }^{87}$

\subsection{Local Marriage Practices under the Laws of the Daimyō}

When the Shöen system began to dissolve between the 14th and 15th centuries and the warrior class gained power, conflicts with landowners increased. To complicate the scenario, in the second part of the 15th century, rival daimyōs

\footnotetext{
84 Wakita. "Marriage and Property in Premodern Japan from the Perspective of Women's History".

85 Wakita and Philips, "Women and the Creation of the 'Ie' in Japan".

86 Hitomi, "Family, women, and gender in medieval society" and Hitomi, "Re-envisioning Women in the Post-Kamakura Age".

87 Wakita, "Marriage and Property in Premodern Japan from the Perspective of Women's History".
} 
began to fight wars, referred to as the Ōnin Wars, marking the beginning of a period of civil wars known in Japanese history as the warring state or the Sengoku period. Many of the so-called daimyō had their own laws regarding their own houses (Ie) and domain (Ryōgoku, 領国), legitimately recognized by the Bakufu and restricted to the boundaries of each daimyō domain, making laws more decentralized and diverse. ${ }^{88}$

This is the context of the arrival of the Christians: a complex system inherited from China, coexisting with different local applications of the law and under the influence of different interpretations of Buddhism and Confucian ideals. Once the daimyōs exercised a position of authority, they took a firm stand on enforcing their laws. The jurisdictions, application of justice, and resolution of conflicts took a more local shape, enough for the Portuguese Álvares to say that, in Japan, "Anyone could do justice in his own house". ${ }^{89}$ In the same way, comparing the Japanese with the people of Europe (gente da Europa), Fróis would also agree that in Europe only those with jurisdiction over the other could punish with death but in Japan anyone could apply the capital punishment within his own domain, reinforcing that each daimyō applied justice himself. ${ }^{90}$

By the time the missionaries arrived in Japan, there were many codes in force, such as the Imagawa kana mokuroku tsuika (1553), of the daimyō Imagawa Yoshimoto; the Jinkaishū (1536), from the daimyō Date Tanemune; Kōshū hatto no shidai (1547), from the daimyō Takeda Harunobu; and the Asakura House Law and Hōjō House Law. Documents from these houses have a lot of potential for shedding light on the Japanese's relationship with the Christians and how law was developed in the period.

For the current purpose and analysis, the House Law of Takeda Shingen, a daimyō who actively fought for the unification of Japan, will be looked at. Article 4 established that marriages should happen inside the domain; any man who married a person from outside the province would create causes for great disturbance, as he may agree to take possession of his wife's estate (Sōryō) and send his "retainers" to serve her family. Therefore, these marriages were strictly forbidden, putting Shingen's vassals at risk of possible severe reprimands if they disobeyed..$^{91}$

\footnotetext{
88 Shizuo and Collcutt, "The development of Sengoku Law".

89 "Quada hum pode en sua casa fazer justiça", in Carta de Jorge Álvares a Francisco de Xavier. Malaca, 1546/1547. Documentos del Japón, 13.

90 Fróis, Tratado em que se contem muito suscinta e abreviadamente algumas contradictões e diferenças.

91 Satō and Ikeuchi, Chūsei hōsei shiryōshu. Buke kahō. Partial translation to English in: Lu, Japan. A Documentary History; and a complete translation to German in Röhl, "Das Gesetz Takeda Shingen's".
} 
Looking now at the Chōsokabe House Law, from the family of Chosokabe Motochika, there is an attempt to establish heavier penalties for moral matters. According to article 33, illicit relations with another man's wife would be punished with the execution of both parties. Unless the guilty pair killed themselves, revenge was permitted, but unnatural cruelty would constitute a crime. If the husband failed to kill the man, or if he was away at the time the offense became known, the people of the village could kill the offender. ${ }^{92}$ Furthermore, this code also stated that if there was no man in the house, no males were allowed to set foot in the house, not even priests. In the outside domain, when a man was not present, a woman was not to visit Buddhist temples or Shintō shrines or go sightseeing.

Regarding marriage practices, whether one's status was high or low, matters of marriage would not be addressed if the understanding of both families had not yet been reached. But if the one planning to marry was a samurai who received over $100 \mathrm{Koku}$ (石), a Japanese unit of volume, it was strictly prohibited to arrange a marriage without the lord's approval. If the matter involved economic issues, inheritance practices changed too, depending on the lord (article 85). In addition, it was strictly forbidden to decide succession matters privately (article 82$) .93$

Further, in the Code of Conduct of Odawara, a fief ruled by Hōjō Soun, maidservants were reported as negligent and stupid in their household affairs. Also, whether of high or low status, women were to be controlled and have their affairs supervised, on account of their innate negligence. ${ }^{94}$

Consequently, the definitions of sexual behavior and its misconducts followed the new structure molded by inheritance, household organization, and marriage norms during the Sengoku period. Inserted in the complex system of land ownership that cannot be classified as private or public, with their own hierarchical system, the Bakufu came to favor male heirs over partible inheritance, choosing to limit women's rights to inherit and transmit their goods. Virilocal marriages were preferred during this time, coming closer to what was established centuries before by the Chinese codes, unlikely in practice before then. ${ }^{95}$ The norms about marriage should also be applied locally: they must follow each domain's rules, although scholars agree that generally it became for the public to reinforce political alliances. "Even among the warrior class,

92 Satō and Ikeuchi, Chūsei hōsei shiryōshu. Buke kahō. trans. English in Jansen, "Tosa in the Sixteenth Century".

93 Lu, Japan. A Documentary History.

94 Steenstrup, "Hōjō Sōun's Twenty-One Articles". See articles 18 and 20.

95 Hitomi, "Re-envisioning Women in the Post-Kamakura Age". 
however, the institution of publicly visible marriage ceremonies evolved slowly until the sixteenth century when the warlords (daimyō) demonstratively asserted their material strength in their unambiguously patrilocal marriage practice". 96

But the decisive blow against women's property was given by Nobunaga, Hideyoshi, and Tokugawa when the commercial guilds known as $\mathrm{Z} a$ were overridden and women lost even their commercial rights; commerce and industry were subsumed within the patriarchal framework. In the 16th century, the right to hold commercial properties passed to men. By the early Edo period, patriarchal authority and control of village households were firmly established. Female merchants disappeared and women were forbidden to brew sake or even enter a brewery. Women's work and general activities were enclosed within the rule of the $I e$ as they became men's helpmates. A dominant feature of the Ie system was that while a wife's work was performed in support of her husband, the results of the labor were considered his achievement.

Finally, in 1603, Tokugawa Ieyasu unified Japan under a new, much more centralized shogunate, which lasted until 1868. During the Tokugawa rule, as the Japanese became more familiar with Confucian ideals, it became common to treat one's wife harshly. Even though missionaries had been expelled from Japan, the persecution of hidden Christians continued. However, in Europe, Japanese marriage was still under discussion, even at the end of the 17th century, while Europeans, especially the Portuguese, were still waiting for Japan to again open its borders to foreigners. ${ }^{97}$

This paper uses a more systematic approach to the missionaries' sources on Japanese marriage by adding a legal historical perspective and using Japanese sources from periods before the arrival of the Christians in Japan. While some scholars already acknowledged the importance of looking at legal sources from different historical periods before the Tokugawa shogunate to understand missionaries' descriptions of Japan in the 16th and 17 th centuries, a systematic approach to the missionaries' and Japanese sources was still lacking.

96 Hitomi, "Re-envisioning Women in the Post-Kamakura Age", 153.

97 In 1669, the Holy Office was still solving questions that were proposed about the marriage of the Japanese. "Dubia et resolutiones de matrimonio Iaponensium. Congreagatio S. Officii habita die XVII iulii MDCLXIX”, in Magnino, Pontificia Nipponica, 173-174. 
Such an approach, applied to the marriage of the Japanese, proved that there was much more to be said beyond the Jesuit descriptions in the sources. The long-term perspective on marriage according to Japanese history connected to Christian sources shows that there is no common idea of sacramentality, salvation, or redemption in marriage according to Japanese traditions; there is also no strict preoccupation with its ceremonies and performance for the whole of Japan. In different periods of the history of Japan, married couples did not necessarily live together, children could be raised by mothers and their families, and inheritance and lineage came from mothers, fathers, or both.

Therefore, four themes stand out from this discussion about Japanese marriage that are determinants for its characterization, both in Japanese legal traditions and in the Christian world: the ceremony of the marriage, its formalities, and the types of relationships involved; the number of wives a man could have; the duration of the relationships or the willingness to stay together forever; and the connection between repudiation and divorce. These topics demonstrate that while Christians were discussing whether the Japanese could understand true marriage according to Christian precepts, the Japanese themselves had different models of marriage according to complex and multilayered legal traditions that need to be understood according to their historical context. In the end, missionaries did not indicate knowledge of what was behind the issues they were discussing regarding Japanese practices and norms and, seen together, the different sources indicate that marriage was not the same all the time in all places. This affirmation is especially true if someone takes into consideration processes of changing norms throughout the centuries in Japanese legal history, culminating in the variety of local norms based on the daimyōs houses' norms.

Regarding the first theme, the following reflects on the missionaries' descriptions about the lack of ceremonies according to their standards. Looking at Japanese norms, one can observe that ceremonies were predicated on Japanese practices beyond the law of the Ritsuryo state, such as the consent of the families, the possibilities for annulling promises of marriage, and the limits of age. Further, sources from the Heian, Kamakura, and Muromachi periods do not emphasize an exact act marking the start of the marriage. Since the Sengoku period, marriages tended to be more political between houses, becoming more public in comparison with the private practices from the periods before, when the families' arrangements counted more for themselves. Of course, this clearly points to virilocal marriage, although the lack of ceremonies at this point could also indicate a difference of social conditions in Japanese society—the higher the social position someone belonged to, the more goods he or she would have to share and the more political alliances to make. 
In terms of the missionaries' descriptions, some of them generalized these ceremonies saying that the Japanese followed a ritual according to their monks, while others said that there were no ceremonies at all and that women used to just move to their husband's houses. Instead of simply looking at Japanese marriage as lacking ceremonies, both sources complexify the debate showing that there is no uniformity that the missionaries' sources could prove. Further, although the debate on types of historical marriage in Japan still exists, Christian sources add another layer of complexities to the period and description. If they usually proved that the prevalent model of the time involved the wife going to the house of the husband, reinforcing recent interpretations of virilocal marriages typical of the Sengoku period (which ironically resembles the norms of the Yôrō code), other descriptions showed that, in fact, even in the 16th century, women had separated patrimony, as Fróis described, contradicting the transformations that happened during the rise of the warrior class and daimyōs. This points to the conclusion that the procedure for the marriage could be much more fluid than imagined.

Regarding the second theme concerning the number of wives, polygamy, which was rejected by the Christians, was legal in Japan since the Ritsuryō state. However, there was a hierarchical distinction between a principal wife and 'secondary' wives, which was clearly practiced among Japanese people. But, again, this is not an undisputed statement according to the missionaries. Some Jesuits mentioned the Japanese having as many wives as they wanted and others mentioned a man with one wife only, which was more convenient in case Jesuits had to solve which wife was the most important. This is particularly structural considering the changing tradition linked to the rise of the samurais and daimyōs in Japan. In early periods, the number of wives in Japanese marriages was never a problem, as the inheritance system was more flexible. However, the rising of the shogunates brought changes involving owning land and its division concerning inheritance rights which would become complicated in situations involving more than one partner.

The third theme, on the duration of relationships in Japan, was also reported by the missionaries as not relevant in constituting a valid marriage among the Japanese. Jesuits repeatedly mentioned the temporary nature of unions and how short they could be; sometimes marriages lasted only some months. This finding was essential to the characterization of the Christian marriage which could only be true if the couple intended to stay together forever. In their sources, there is repetitive information on how the Japanese did not want to stay eternally united and that repudiation, our next topic, was in their thoughts since before the marriage began as a possibility they could resort to when one of the spouses did not want to stay in the union. Indeed, the stability of the 
relations was not relevant for the marriage. This can be inferred by the possibility of marrying and remarrying during many centuries in Japan, which was negotiated by the families, as well as the possibility of sending women away. In fact, for the Japanese, family relationships were not a permanent institution throughout the historical periods and, as such, the willingness to stay together forever could not be understood as the core concept for the union as this was as difficult for them to grasp as the notion of an inner will.

Finally, the fourth theme, repudiation, is important because the many different ways of getting a divorce were common in Japan since the Ritsuryō state, although the process was different for a man and for a woman, particularly for remarrying. The Yōrō code itself and the practices since the Nara period seemed to be congruent on this matter. But in the Sengoku period, divorcing would not have been possible in some houses' laws without the lord's authorization, pointing to the political consequences of such a decision. This points to the necessity of a deeper analysis of possibly contrasting information between practices and norms established by the unstable governance in this period. Jesuits, from their side, observed in their reports that, after being repudiated, women were sent back to their parents' houses. Others tried to find reasons for the repudiation and separation, distinguishing a good and a bad woman, or stating general descriptions, such as separation for a small incident. Again, there are indications in the sources that divorce was a very well-known institution for the Japanese and was commonly practiced throughout the centuries. In Europe, although divorce was also possible under some circumstances in the ecclesiastical jurisdiction, to the Jesuits the Japanese conditions seemed to be much more trivial and flexible than those of the Europeans.

\section{5}

\section{Conclusions}

As the missionaries did not have a complex idea about the true intentions of the Japanese because of the conditions of the mission, the differences of the cultures that met for the first time, and the difficulties caused by misunderstandings due to language, it is perhaps only now possible to take a closer look at the descriptions of the missionaries according to a legal history perspective that incorporates Japanese sources. Scholars insisted on writing the history of the Christian Century in Japan using only missionaries' sources, even when they were trying to decipher the (inner) motivations of the converted Japanese.

Therefore, this chapter insists, first, that scholars should interpret this period of Japanese and Iberian histories using the most sources possible in a connected way, overcoming the tendency to rely only on Christian ones. 
Second, a specific legal historical approach can offer tools for an even more complex interpretation of the sources. Third, recent developments in women's history in Japan can contribute to the development of a women's legal history based on normativities as a methodological tool to read legal history beyond written laws and closer to practices. This proposal, defended in this paper, can complexify specific institutions and behaviors in the Christian Century in Japan, help to understand the discrepancy among missionaries' descriptions, and question a static view on Japanese normativities by highlighting the difference in practices in various places of Japan in the 16th and 17th centuries.

As this initial analysis shows, this research requires much more development considering that there is a complexity that can only be understood if legal history is viewed not as a single process of reading written laws, but as a complex process always in the making that includes practices, norms, principles, discourses and rules that vary according to places, institutions, and conflicts connected to a global world. This is true in different stages at this point: in deepening the application of the Ritsuryō based on other sources and in the necessity to go further in the study of normativities through the Nara, Heian, Kamakura, Muromachi, and Sengoku periods. For this last one, it is now imperative that the house laws of daimyōs, who were politically and religiously closer to the missionaries, are studied in order to problematize a more explicit relation between local governance and the Japan mission. This could help to connect the documents from the houses of the Sengoku period to the specific relations they had with Christians and explore in depth the Christian Japanese that changed the practices of religious rituals in Japan.

\section{Bibliography}

\section{Manuscripts}

Archivo de la Universidad de Santo Tomas (AUST), Manila. Varios Tratados Manuscritos y Varias Consultas. Siglo XVII, 1-427.

Arquivo Nacional da Torre do Tombo (ANTT), Lisboa, Comentários do Padre Francisco Rodrigues Da Companhia De Jesus sobre os casos versados na Índia e suas partes com muitas outras resoluções mui importantes e necessárias aos confessores, com seu Index de todas as coisas que neste livro se contém. Resposta de alguns cazos que os padres de Japão Mandaram perguntar, Manuscritos da Livraria, no. 805 (Codex 805). Biblioteca da Ajuda (вA), Lisboa, Jesuítas na Ásia, Série Miscelâneas, Cód. Ms. 49-VI-6. Hossō shiyōshō, 1662, digitalized by Waseda University. See: http://www.wul.waseda .ac.jp/kotenseki/html/wao3/wao3_02482/index.html (last accessed 04.18.2021).

Roman Archives of the Society of Jesus (RASJ), Rome, Japonica Sinica, 6, 4V-5r. 


\section{Printed Sources}

Documenta Indica VI (1563-1566), edited by Wicki, Josef, Rome 1948.

Documenta Indica VII (1566-1569), edited by Wicki, Joseph, Rome 1962.

Documentos del Japón, 1547-1557, Monumenta Historica Societatis Iesu, editados y anotados por Juan Ruiz-de-Medina, Rome 1990.

Fróis, Luís, Tratado em que se contem muito suscinta e abreviadamente algumas contradictões e diferenças de custumes antre a gente de Europa e esta Provincia de Japão, Tokyo 1955 .

The Laws of the Muromachi Bakufu. Kemmu Shikimoku (1336) \& Muromachi Bakufu Tsuikahō. trans. Kenneth A. Grossberg and Kanamoto Nobuhisa, Tōkyō 1981.

Leite, Serafim, Monumenta Brasiliae, tomo 1, Rome 1956.

López Gay, Jesus, El Matrimonio de los Japoneses: Problema y Soluciones según un ms. inédito de Gil de la Mata, Rome 1964.

López Gay, Jesus, “Un Documento Inédito del P.G. Vázquez (1549-1604) sobre los Problemas Morales del Japón", in Monumenta Nipponica 16:1-2 (1960): 118-16o.

Magnino, Leo, Pontificia Nipponica. Le relazioni tra la Santa Sede e il Giappone attraverso i documenti pontifici. Parte prima (s. XVI-XVII), Rome 1947.

Miraculous Stories from the Japanese Buddhist Tradition. The Nihon Ryōiki of the Monk Kyōkai, trans. and edited Kyoko Motomochi, Nakamura, London 1973.

Philippi, Donald, Norito: A translation of the ancient Japanese rituals prayers, New Jersey 1990.

Röhl, Wilhelm, "Das Gesetz Takeda Shingen's”, in Oriens Extremus 6:2 (1959): 210-235.

Shintei zōho kokushi taikei, xxII, Tōkyō 1939, "Ryō no Gige".

Shintei zōho kokushi taikei, xxIv, Tōkyō 1966, "Ryō no Shuge".

Steenstrup, Carl, "Hōjō Sōun's Twenty-One Articles: The Code of Conduct of the Odawara Hōjō", in Monumenta Nipponica 29:3 (1974): 283-303.

Valignano, Alejandro, Sumario de las Cosas de Japon (1592), Tokyo 1954.

Valignano, Alejandro, Adiciones del Sumario de Japon (1583), Tokyo 1954.

Vera Cruz, Antonio de la, Espejo de los Conyuges (1556), trans. Carolina Ponce Hernández, México 2007.

Yoshie, Akiko, Ijuin, Yōko and Piggott, Joan, 日本令にみるジェンダーその(1)戸令, Gender in the Japanese Administrative Code Part 1: Laws on Residence Units, Ritsuryō Translation project, usc Project for Premodern Japan Studies.

Yoshie, Akiko, Ijuin, Yōko and Piggott, Joan, 日本令にみるジェンダーその (2) 後宮職員 令 (上), Gender in the Japanese Administrative Code: Laws on Officials in the Back Palace(1), Ritsuryō Translation project, Usc Project for Premodern Japan Studies.

\section{Literature}

Asakawa, Kenichi, The early institutional life of Japan, Tokyo 1903.

Boxer, Charles Ralph, The Christian Century in Japan. 1549-1650, Manchester 1993. 
Castelnau, Charlotte de, "Le mariage des infidèles au XVIe siècle : doutes missionnaires et autorité pontificale", in: Mélanges de l'Ecole française de Rome. Italie et Méditerranée, tome 121, no. (2009), Administrer les sacrements em Europe et au Nouveau Monde : la curie romaine et les dubia circa sacramenta, 95-121.

Duve, Thomas, "Pragmatic Normative Literature and the Early Modern Iberian Empires

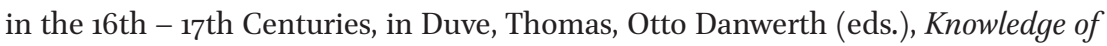
the pragmatici: Legal and Moral Theological Literature and the Formation of Early Modern Ibero-America, vol. 1, Leiden 2020.

Ehalt, Rômulo da Silva, "Goa no Iezusukai Shingakusha to Nihon no Doreika Mondai", in: Kirishitan Bunka Kenkyukai Kaiho, 154, Kirishitan Bunka Kenkyuka (2019): 1-14.

Ehalt, Rômulo da Silva, "Casuística nos Trópicos: a pragmática teológico-moral de Francisco Rodrigues na Ásia portuguesa (séculos XVI e XVII)", in Revista de História da Sociedade e da Cultura 19 (2019): 399-418.

Engi-shiki: Procedures of the Engi era, trans. Felicia Gressit Bock, books I-V, Tōkyō 1970. Engi-shiki: Procedures of the Engi era, trans. Felicia Gressit Bock, books VI-X, Tōkyō 1972.

Gay, Suzanne Marie, The moneylenders of late medieval Kyoto, Honolulu 2001.

Goodwin, Janet, Selling Songs and Smiles. The Sex Trade in Heian and Kamakura Japan, Honolulu 2007.

Goodwin, Janet, "Shadows of Transgression: Heian and Kamakura constructions of Prostitution", in Monumenta Nipponica 55:3 (2000): 327-368.

Hall, John Carrey, Japanese Feudal Law. Studies in Japanese Law and Government. Washington 1979.

Hayakawa, Noriyo, “The Development of Women's History in Japan”, in: Offen, Karen, Pierson, Ruth Roach, Rendall, Jane (eds.), Writing Women's History: International Perspectives, Basingstoke 1991.

Hesselink, Reinier, “The Capitães Mores of the Japan Voyage: a group portrait”, in International Journal of Asian Studies 9:1 (2012): 1-41.

Hideo Lavy, Ian, The Ten Thousand Leaves. A Translation of the Man'Yōshū, Japan's Premier Anthology of Classical Poetry, Princeton 1981.

Igawa, Kenji, "The encounter between Europe and Japan", in: Acta Asiatica. Bulletin of the Institute of Eastern Culture, Intercultural Contact in Medieval Japan 13 (2012): 77-94.

Inoue, Mitsusada, Ritsuryō, Nihon shisō taikei 3, Tōkyō 1976.

Inoue, Kiyoshi, Nihon joseishi 1, Kyōtō 1952.

Ishii Shiro, Beyond Paradoxology. Searching for the logic ofJapanese History, Tōkyō 2007. Jansen, Marius B., "Tosa in the Sixteenth Century: The 100 Article Code of Chosokabe Motochika", in Hall, John Whitney, Jansen, Marius B. (eds.), Studies in the Institutional History of Early Modern Japan, Princeton 2015. 
Katsumata, Shizuo and Collcutt, Martin, "The development of Sengoku Law", in Hall, John Whitney, Nagahara, Keiji and Yamamura, Kōzō (eds.), Japan Before Tokugawa, Princeton 1981.

Lobato, Manuel, "Notas e Correcções para uma Edição Crítica do Ms. da Livraria N. 805 (IAN/TT), a Propósito da Publicação de um Tratado do Pe. Manuel de Carvalho SJ", in Anais de História de Além-Mar 3 (2002): 389-408.

Lu, David J., Japan. A Documentary History. Volume 1. The dawn of history to the late Tokugawa Period, London 2010.

Mass, Jeffrey, Lordship and Inheritance in Early Medieval Japan. A Study Of The Kamakura Sōryō System, Stanford 1989.

Mccullough, William H., "Japanese Marriage Customs in the Heian Period", in Harvard Journal of Asiatic Studies 27 (1967): 103-167.

Meeks, Lori, "Buddhist Renunciation and the Female Life Cycle: Understanding Nunhood in Heian and Kamakura Japan", in Harvard Journal of Asiatic Studies 70:1 (2010): 1-59.

Piggott, Joan, "Keeping Up With the Past. New Discoveries Enrich Our Views of History", in Monumenta Nipponica 38:3 (1983): 313-319.

Piggott, Joan, “Mokkan. Wooden Documents from the Nara Period", in Monumenta Nipponica 45:4 (1990): 449-470.

Piggott, Joan, The Yōrō Ritsuryō Sōniryō. Laws on Monks and Nuns, Ritsuryō Translation project, Usc Project for Premodern Japan Studies, Los Angeles, http://www.uscppjs .org/ritsury-translation-project (last accessed 04.18.2021).

Pinto, Ana Fernandes, and Pires, Silvana Remédio, "The 'Resposta que alguns Padres de Japão mandaram perguntar': a clash of strategies?”, in Bulletin of Portuguese/ Japanese Studies 10-11 (2005): 9-6o.

Reynolds, Philip, How Marriage Became One of the Sacraments. The Sacramental Theology of Marriage from its Medieval Origins to the Council of Trent, Cambridge 2016.

Sansom, George Bailey, "Early Japanese law and administration", in Transactions of the Asiatic Society ofJapan 2, vol. 9 and Transactions of the Asiatic Society ofJapan 2, vol. 11, Tokyo 1932-1933.

Satō, Shin'ichi and Ikeuchi, Yoshisuke, Chūsei hōsei shiryōshu, Buke kahō, Tōkyō 1965.

Satō, Shin'ichi and Ikeuchi, Yoshisuke, Chūsei hōsei shiryōshu, Muromachi Bakufu hō, vol. 2. Tōkyō 1969.

Sekiguchi, Hiroko, "The Patriarchal Family Paradigm in Eighth-Century Japan”, in Ko, Dorothy, Haboush, JaHyun Kim, and Piggott, Joan R. (eds.), Women and Confucian Cultures in Premodern China, Korea, and Japan, Berkeley 2003, 27-46.

Souyri, Pierre F., "Luís Fróis et l'histoire des femmes japonaises", in Carneiro, Roberto and Matos, Artur Teodoro de (eds.), O Século Cristão do Japão: Actas do Colóquio Internacional Comemorativo dos 450 Anos de Amizade Portugal-Japão, 1543-1993 (Lisboa, 2 a 5 de Novembro de 1993), Lisboa 1994, 630-644. 
Tonomura, Hitomi, "Family, women, and gender in medieval society", in: Friday, Karl (ed.), Routledge Handbook of Premodern Japanese History, London 2017, 275-295.

Tonomura, Hitomi, "Re-envisioning Women in the Post-Kamakura Age", in: Mass, Jeffrey (ed.), The Origins of Japan's Medieval World. Courtiers, Clerics, Warriors, and Peasants in Fourteenth Century, California 1997.

Tutino, Stefania, Uncertainty in Post-Reformation Catholicism. A History of Probabilism, Oxford 2017.

Vu Thanh, Hélène, "Introducing Tridentine Marriage: The Jesuits' Strategy in Japan (Sixteenth and Seventeenth Centuries)", in Rechtsgeschichte - Legal History 27 (2019):143-151.

Wakita, Haruko and Gay, Suzanne, "Marriage and Property in Premodern Japan from the Perspective of Women's History", in The Journal of Japanese Studies 10:1 (1984): 73-99.

Wakita, Haruko and Philips, David, "Women and the Creation of the "Ie" in Japan: an Overview from the Medieval Period to the Present", U. S. - Japan Women's Journal 4 (1993): 83-105.

Wakita, Haruko, Women in Medieval Japan. Motherhood, Household Management and Sexuality, trans. Alison Tokita, Victoria 2006.

Ward, Haruko Nawata, Women Religious Leaders in Japan's Christian Century, 1549-1650, London and New York 2016.

Wirbser, Rouven, "A Law Too Strict? The Cultural Translation of Catholic Marriage in the Jesuit Mission to Japan", Translating Catechisms, Translating Cultures, Leiden, The Netherlands 2017 .

Yoshie, Akiko, "Gender in Early Classical Japan. Marriage, Leadership, and Political Status in Village and Palace", Monumenta Nipponica 60:4 (2005): 437-479.

Zagorin, Perez, Ways of Lying: Dissimulation, Persecution and Conformity in Early Modern Europe, Cambridge, Massachusetts 1990. 